\title{
A Legislatively Mandated Council: A Model for Palliative Care Policy Integration
}

\author{
Cynda Hylton Rushton, Ph.D., R.N., FAAN ${ }^{1}$ and Jack Schwartz, J.D.?
}

\begin{abstract}
Mechanisms are needed to foster discussion of policy choices about end-of-life care, identify areas of general agreement, and clarify possible areas of disagreement. The Maryland State Advisory Council on Quality Care at the End of Life (MSAC), created by legislation as a permanent part of Maryland government, is one such mechanism. We describe the rationale for creating the MSAC, its operational features, and some of its successes and challenges. Given state-to-state variation in many aspects of health care organization and financing, we do not present the MSAC as a model to be adopted in every state. The MSAC's body of work over 8 years indicates that the model can be an effective catalyst for positive change in end-of-life policy making. Reformers elsewhere should consider this model, with an eye to both the MSAC's accomplishments and areas in which a different approach might be more fruitful.
\end{abstract}

\section{Introduction}

I MPROVING CARE FOR PATIENTS nearing the end of life has an important public policy dimension, because "legal, organizational, and economic obstacles conspire to obstruct reliably excellent care." ${ }^{1}$ Although public discourse about end-of-life care can be subverted for short-term political gain, ${ }^{2}$ care delivery for seriously ill patients and its financing are inevitable and legitimate issues in health care reform initiatives. $^{3}$ For example, well-integrated palliative care and hospice services should be a core component of the patientcentered focus required of accountable care organizations. ${ }^{4}$ Yet, this aspect of coordinated, patient-centered care will suffer if state law and policy pose significant barriers to effective advance care planning and implementation.

The importance of the policy dimension has been recognized by recent major philanthropic initiatives aimed at improving end-of-life care. For example, the Open Society Institute's Project on Death in America identified "the shaping of governmental and institutional policy" as a priority area for its grant funding. ${ }^{5}$ In a report issued by Last Acts, a national coalition supported by the Robert Wood Johnson Foundation, much attention was given to state policies on advance directives and pain management. ${ }^{6}$ Further, the Robert Wood Johnson Foundation's Community-State Partnerships to Improve End-of-Life Care, an $\$ 11.25$ million program that supported state and local coalitions in about half the states, was based on the premise that state policy markedly affects endof-life care. ${ }^{7}$

At the federal level, even before the uproar over advance care planning provisions in health care reform legislation, entities within the U.S. Department of Health and Human Services (DHHS) produced extensive analyses on this topic. ${ }^{8,9}$ The National Hospice and Palliative Care Organization identified the development of "a comprehensive end-of-life care public policy agenda" as one of its strategic areas. ${ }^{10}$ The National Priorities Partnership, comprising 48 member organizations and offering consultative support to DHHS, has identified palliative and end-of-life care as one of its key priority areas. ${ }^{11}$

Advocates from divergent perspectives agree that policy making by state legislatures and courts can dramatically affect the nature and quality of end-of-life care. For example, Americans United for Life reported on approximately 90 bills related to end-of-life issues considered by state legislatures in 2010. ${ }^{12}$ Compassion and Choices, a "choice-in-dying" advocacy organization, has identified "the trend in the states to improve end of life choices" and has an active state-court litigation agenda. ${ }^{13}$

State-level activity is of interest not only to organizations with their own ideological premises but also to clinicians and others seeking the optimal policy environment for good endof-life care. Mechanisms are needed to foster discussion of policy choices, identify areas of general agreement, and clarify

\footnotetext{
${ }^{1}$ Johns Hopkins University Schools of Nursing and Medicine, Baltimore, Maryland.

${ }^{2}$ University of Maryland School of Law, Baltimore, Maryland.

Accepted July 5, 2011.
} 
possible areas of disagreement. The Maryland State Advisory Council on Quality Care at the End of Life (MSAC), created by legislation as a permanent part of Maryland government, is one such mechanism. Massachusetts has created a similar statutory entity, ${ }^{14}$ but this approach remains rare. Another state, West Virginia, has a legislatively supported, universitybased educational and resource center. ${ }^{15}$ Other models worthy of consideration and refinement include time-limited groups established by executive order, such as the former Michigan Commission on End of Life Care, ${ }^{16}$ or nongovernmental coalitions, such as the California Coalition for Compassionate Care. ${ }^{17}$

This article describes the rationale for creating the MSAC, its operational features, and some of its successes and challenges. Given state-to-state variation in many aspects of health care organization and financing ${ }^{18}$ as well as political climate, we do not present the MSAC as a model to be adopted in every state. However, a well-considered approach to state-level policy analysis and advocacy is essential. Our account is intended to help inform the work of groups looking to influence policy making in other states.

\section{Creation of the MSAC}

Before MSAC, end of-life policy making in Maryland was characterized by ad hoc coalition-building. Most notably, Maryland's comprehensive law on advance directives, default surrogate decision making, and medical futility, enacted in 1993, was a melding of the work of two separate, informally constituted drafting groups. ${ }^{19,20}$

After its enactment, then-Attorney General J. Joseph Curran, Jr. worked with the Johns Hopkins University's Bioethics Institute to convene an advisory panel and gather data on the impact of the law on aspects of end-of-life care. ${ }^{21}$ Funded through a planning grant from the Robert Wood Johnson Foundation, public discussions and survey results were a useful step in identifying areas in need of further policy work, especially regarding pain management. ${ }^{22}$ These specific activities and, more generally, the respectful discussions among a diverse group of stakeholders fostered interest in ongoing dialogue.

The option of continuing the existing partnership was inherently fragile, because sustaining it indefinitely depended on both the interest of the incumbent attorney general and grant funding. An alternative, creation of an advisory panel established by executive order, relied upon gubernatorial support. Because executive orders can be revoked as readily as they can be issued, the existence of the panel would have depended on the political goodwill of the governor at any given time. Moreover, such panels invariably are created for a specific reporting task by a defined conclusion date. By con- trast, many end-of-life policy issues are complex and multifaceted (for example, regulatory requirements for implementation of care plans in a wide array of facilities) and, consequently, are best addressed incrementally over time, without artificial deadlines.

The Office of the Attorney General and advisory panel members judged that the preferable approach was the creation of a permanent, independent advisory commission through legislation. In 2002, the Office of the Attorney General garnered support among interested groups and legislators for a bill to create the MSAC. Passed nearly unanimously by the Maryland General Assembly, the bill became effective in October 2002. ${ }^{23}$ The legislation gave the MSAC a broad mandate, including responsibility for data gathering, policy analysis, advocacy, and education (Table 1). Following common practice for legislatively created advisory groups, the membership is specified by category (Table 2). ${ }^{24}$ Authority to appoint members with the requisite qualifications and to designate the chair is vested in the governor. Members receive no compensation, nor does the MSAC itself receive appropriated funds. Instead, staff support and technical assistance are provided by the Department of Aging and the Office of the Attorney General. ${ }^{25}$

\section{Initiatives and Processes of the MSAC}

Issues affecting end of-life care are diverse in scope, importance, and urgency. Advisory groups require focus to be effective, sustainable, and avoid paralysis. Priorities must be established and adhered to and mechanisms created to be responsive to immediate matters (e.g., proposed legislation nearing a vote). The MSAC sought to maintain this balance through a combination of strategic planning, public engagement, and meetings timed to allow comment on legislative proposals.

The MSAC, convened in April 2003, intentionally created a culture of inclusion and flattened hierarchy. Meetings were held 3 to 4 times/year in a central location, agendas were accessible online, and all attendees were afforded the opportunity to participate, regardless of their formal role. Of symbolic importance, all participants were seated together, both for exchange of information and discussion of agenda items. The complementary roles of the chair and the assistant attorney general modeled collaboration and respect for each person's knowledge, skills, and perspectives. After each meeting, minutes and documents were accessible online.

In early meetings, the MSAC used a facilitated prioritysetting process, elaborated through a subcommittee structure, to determine priority areas and action items (Table 3). A facilitator skilled in strategic planning was an invaluable asset to the process.

Table 1. Statutory Responsibilities of the MSAC

\begin{tabular}{lcc}
\hline Analysis & Advocacy & Other \\
\hline $\begin{array}{l}\text { Monitor trends in the provision of care } \\
\text { to Marylanders with life-limiting illnesses. }\end{array}$ & $\begin{array}{c}\text { Provide recommendations } \\
\text { to executive branch agencies } \\
\text { about activities affecting } \\
\text { end-of-life care. }\end{array}$ & $\begin{array}{c}\text { Promote, through direct participation } \\
\text { or otherwise, public and professional } \\
\text { education on end-of-life care issues. }\end{array}$ \\
$\begin{array}{c}\text { Study the impact of state law and policy } \\
\text { on end-of-life care. }\end{array}$ & $\begin{array}{c}\text { An bills affecting end-of-life care. } \\
\text { on by the governor or legislature. }\end{array}$ \\
\hline
\end{tabular}


TAble 2. Membership of the MSAC

Government agencies

(one representative each)

Attorney General

State Senate

House of Delegates

Department of Aging

Department of Health and Mental Hygiene

Department of Disabilities
Health care professionals and facilities

Physician with end-of-life care experience

Nurse with end-of-life care experience

Physician with long-term care experience Nurse with long-term care experience

Pharmacist with end-of-life care experience

Hospice representative

Hospital representative

Nursing home representative
Other representatives

Two representatives from advocacy groups for end-of-life care

Two representatives of the general public with experience in end-of-life care or long-term care issues

Representative from health insurers

Representative from managed care organizations

Two representatives from religious groups

Lawyer
Regular meetings, while crucial to the MSAC's ongoing work, were considered insufficient as a method of public outreach. Twice the Council convened "Stakeholder Summits," which enabled a larger and more diverse group of people to discuss issues and formulate recommendations. These broader gatherings, summarized in Table 4, also served public education and outreach objectives.

Although some of the items reflected in Tables 3 and 4 have not been acted upon, many have. Table 5 reflects examples of some of the actions that were implemented including the recent enactment of a Maryland version of the Physician Orders for Life-sustaining Treatment (POLST). ${ }^{26}$ In one instance, the MSAC was able to respond quickly after a privately adopted barrier to quality care was brought to its attention by successfully encouraging an outpatient endoscopy center to reconsider its policy of uniformly disregarding patients' advance directives. ${ }^{27}$

One virtue of the MSAC is that it is informed by the practical experience of its members and participating stakeholders, which expands the discussion about immediate issues to consider the broader policy dimensions. The most noteworthy initiative of this kind involved pediatric palliative care. As indicated in Tables 2 and 3, the MSAC itself, reinforced by ideas discussed at the 2006 Stakeholders' Summit and prior efforts, ${ }^{28}$ identified the needs of children with life-threatening conditions as an area of strategic focus. The MSAC, with key support from other state agencies, the Pediatric Palliative Care Coalition of Maryland, and the Maryland Hospice and Palliative Care Network, won the endorsement of the Maryland General Assembly for a comprehensive report on pediatric palliative care. ${ }^{29}$ The resulting report from the MSAC and the Maryland Health Care Commission discussed various policy options, including state-mandated insurance coverage for pediatric palliative care and various steps in a voluntary initiative, including increased use of case management techniques by both Medicaid and private insurers. ${ }^{30}$ This effort amounted to a preparatory step to promote more effective implementation in Maryland of the provisions in the federal health care reform legislation on access of pediatric patients to hospice services and more broadly, palliative care. ${ }^{31}$

One danger for the MSAC is the potential to be drawn directly into the controversy over issues such as physicianassisted suicide. This controversy is not as active in Maryland as elsewhere. Maryland law prohibits assisting a suicide, whether by a physician or anyone else ${ }^{32}$; the Maryland General Assembly has consistently rejected proposals to emulate the Oregon approach of legalizing and regulating physicianassisted suicide; and Maryland does not allow citizeninitiated legislative proposals. Consequently, the MSAC has not faced the potentially crippling divisiveness that such a

Table 3. Selected MSAC Priority Areas and Action Items

Care planning and advance directives

Identify legal/ethical barriers to integrating palliative care into ongoing clinical care.

Develop model policy/procedures for systemic improvement in facilities' end-of-life care.

Draft a more user-friendly advance directive form.

Conduct a public education campaign on advance care planning.

Find a means of distributing the " 5 Wishes" form.

Develop materials for workplace initiatives in advance care planning.

Develop a Maryland POLST (Physician Orders for Life-Sustaining Treatment).
Vulnerable patients

Assess pediatric palliative care services in Maryland.

Gather demographic data on use of hospice services by pediatric and adult patients

Assess advance care planning in minority communities.

Collect data on Medicaid reimbursement and hospice use in nursing homes.

Identify approaches to improve care for terminally ill foster children.

Identify particular needs of patients/family caregivers of patients with dementia. 
Table 4. Summary of Stakeholder Summits

First Stakeholders' Summit (October 3, 2004)

Fifty, representing a range of health care, legal, disability rights, consumer, and religious organizations

Topic $1 \quad$ Ethical framework for delivery of quality end-of-life care

Topic 2 Proposed "Patient Plan of Care" form
Second Stakeholders' Summit (November 13, 2006)

Forty, with similarly diverse representation

Improving palliative care for children with life-threatening conditions

Improving palliative care for patients with dementia

Action Plans proposal would create. However, controversy can arise obliquely. A 2009 bill that would have required health care providers to provide counseling to terminally ill patients about care options was strongly opposed by various groups concerned about bias toward treatment refusal and the potential encouragement of assisted suicide. Ultimately, the bill was diluted to authorizing a study by the Attorney General's
Office of access to hospice care, in which the MSAC was a key participant.

\section{Lessons to be Drawn}

The MSAC's body of work over 8 years indicates that the model can be an effective catalyst for positive change in

Table 5. Selected impact of MSAC Initiatives

\begin{tabular}{|c|c|c|c|}
\hline Priority area & Specific initiative & Process & Outcome \\
\hline $\begin{array}{l}\text { Care planning } \\
\text { and advance } \\
\text { directive }\end{array}$ & $\begin{array}{l}\text { Identify legal/ethical barriers to } \\
\text { integrating palliative care into } \\
\text { ongoing clinical care. } \\
\text { Develop a model of policy/ } \\
\text { procedures for systemic } \\
\text { improvement in facilities' end- } \\
\text { of-life care. }\end{array}$ & $\begin{array}{l}\text { MSAC members drafted and } \\
\text { vetted a draft ethical } \\
\text { framework for review by key } \\
\text { stakeholders attending a } \\
\text { Stakeholders' Summit and } \\
\text { revised based on feedback. }\end{array}$ & $\begin{array}{l}\text { An "ethical framework" is in } \\
\text { place to assist facilities in } \\
\text { adopting policies and } \\
\text { procedures better aligned with } \\
\text { excellence in end-of-life care. }{ }^{34}\end{array}$ \\
\hline $\begin{array}{l}\text { Care planning } \\
\text { and advance } \\
\text { directives }\end{array}$ & $\begin{array}{l}\text { Draft a more user-friendly } \\
\text { advance directive form in the } \\
\text { Maryland Health Care } \\
\text { Decisions Act. } \\
\text { Conduct a public education } \\
\text { campaign on advance care } \\
\text { planning. }\end{array}$ & $\begin{array}{l}\text { The MSAC and assistant attorney } \\
\text { general drafted, refined, and } \\
\text { vetted proposed changes to } \\
\text { key stakeholders. } \\
\text { Members of the MSAC and } \\
\text { key partners communicated } \\
\text { availability, and created } \\
\text { educational sessions for } \\
\text { clinicians and the public. }\end{array}$ & $\begin{array}{l}\text { The statutory advance directive } \\
\text { form has been revised. }{ }^{35} \text { New } \\
\text { advance directive forms } \\
\text { include key provisions that } \\
\text { allow for individuals to choose } \\
\text { how they wish their surrogates } \\
\text { to interpret their preferences } \\
\text { for life-sustaining therapies. } \\
\text { The new forms are available on } \\
\text { the attorney general's } \\
\text { website. } \\
\text { The MSAC's efforts created the } \\
\text { platform for others to expand } \\
\text { their priorities, including the } \\
\text { development of a manual for } \\
\text { nursing home administrators } \\
\text { and a document guiding } \\
\text { health care agents in their role } \\
\text { as surrogate decision makers. }\end{array}$ \\
\hline $\begin{array}{l}\text { Care planning } \\
\text { and advance } \\
\text { directives }\end{array}$ & $\begin{array}{l}\text { Develop a Maryland POLST } \\
\text { (Physician's Orders for Life- } \\
\text { Sustaining Treatment). }\end{array}$ & $\begin{array}{l}\text { The MSAC helped lead a 2-year } \\
\text { effort to gain consensus on the } \\
\text { contents of the form and the } \\
\text { obligations surrounding its } \\
\text { use. }\end{array}$ & $\begin{array}{l}\text { Subsequently, the Maryland } \\
\text { legislature passed a law } \\
\text { authorizing a Maryland } \\
\text { version of POLST, to be } \\
\text { implemented in Fall 2011. (25) }\end{array}$ \\
\hline $\begin{array}{l}\text { Vulnerable } \\
\text { patients }\end{array}$ & $\begin{array}{l}\text { Assess pediatric palliative care } \\
\text { services in Maryland. }\end{array}$ & $\begin{array}{l}\text { Concurrent with a Pediatric } \\
\text { Palliative Care Summit } \\
\text { sponsored by the Johns } \\
\text { Hopkins Children's Center, the } \\
\text { MSAC explored the issues } \\
\text { raised in the summit report } \\
\text { with key stakeholders. }\end{array}$ & $\begin{array}{l}\text { The MSAC sought and obtained } \\
\text { a legislative mandate for a } \\
\text { formal report by the MSAC } \\
\text { and Maryland Health Care } \\
\text { Commission to the legislature. } \\
\text { This policy-oriented report } \\
\text { was submitted in January } \\
\text { 2008. }\end{array}$ \\
\hline
\end{tabular}


end-of-life policy making. Reformers elsewhere should consider this model, with an eye to both the MSAC's accomplishments and areas in which a different approach might be more fruitful.

One characteristic of the MSAC that is simultaneously a benefit and risk is its independence. Because it is not part of any major state agency, its recommendations are untainted by conflict of interest, real or perceived. Without a regulatory role of any kind, the MSAC is better able to engage stakeholders from regulated professions and facilities such as nursing homes. However, the lack of solid institutional moorings or a sustained funding source means that the MSAC is dependent on the goodwill of others and lacks resources to hire staff or contract for consultation or research. The Department of Aging and the Office of the Attorney General have never failed to give the MSAC the staff support that it has needed but have lacked the resources to conduct empirical research themselves or to fund the MSAC to do so. If attitudes change or budgetary distress becomes more acute and as a result staff support is allocated elsewhere, the MSAC would struggle to continue its work. Neither the chairperson nor the other volunteer members of the MSAC can be expected to carry out essential logistical and follow-up activities themselves. Others who consider advocating for a similar mechanism for end-oflife policy advice should focus on resources, given that quality advice is not cost-free. Key organizational stakeholdershospitals, hospice organizations, professional societies or universities-could commit portions of their staff members' time to data collection, policy and financial analysis, education, and other aspects of the agenda.

The MSAC's fundamental character as an independent group of interdisciplinary experts and citizen advocates that meets sporadically presents a second problem: timely decision making against firm deadlines. When an amendment to a bill, for example, is to be considered by a legislative committee in 48 hours, the MSAC's normal process of inclusive participation in a wide-ranging discussion, with the goal of developing broad consensus, is not feasible. Yet, it seems inconsistent with the MSAC's underlying purpose if it always stays silent when time constraints do not allow for its normal deliberation. Others may devise a better approach than the MSAC's for realistically participating in a fast-moving legislative process.

Although both its membership and informal roster of nonmember participants are diverse professionally, the MSAC has struggled to find effective ways of engaging the broader community. The two invitational "Stakeholder Summits" were helpful in raising awareness about key endof-life issues but were insufficient in achieving broader policy objectives. Expansion of the model through greater collaboration with hospitals, societies, state and local agencies, and universities to co-sponsor and design such events may be a fruitful option. Although the MSAC has pursued various avenues, greater community involvement in the policy making process, especially by racial and ethnic minorities and persons with disabilities, is needed.

Finally, policy reformers should consider whether the narrow focus on end-of-life care is the best option for gaining policy support for issues that impact people living with lifethreatening conditions. In our experience, the narrow focus on end-of-life care helped to shape a useful working agenda and did not create public or policy concern. However, each state considering adoption of this model should assess its own readiness and culture to determine the best strategy. Given the renewed political backlash around issues that are perceived to undermine respect at the end of life, a title that encompasses the broader palliative care agenda may be advisable. Initiatives such as the Coalition to Transform Advanced Care are pursuing broader concepts and language. ${ }^{33}$

\section{Conclusion}

Policy that influences the environment in which care is delivered should be congruent with patient-centered clinical care. The MSAC represents an innovative approach to promoting state end-of-life policy that serves the interests of patients with life-limiting illness. Created legislatively, the MSAC has a permanent place in Maryland government, so persons who identify problems or wish to advocate for change will have an institutional locus to present their concerns and enlist support.

At a time when federal policy is both promising and uncertain, and when state policy makers remain very active on issues affecting end-of-life care, establishing a framework for collaboration and consensus-building at the state level is all the more important. The MSAC, with a record of accomplishment across a range of issues but difficulties in some areas, is a worthwhile model for consideration by advocates for end-of-life policy reform in other states.

\section{Acknowledgments}

We express our deep gratitude to the members of the State Advisory Council on Quality Care at the End of Life and the staff of the Maryland State Attorney General's Office and Office of Aging.

\section{Author Disclosure Statement}

No competing financial interests exist. Dr. Rushton was the former chair of the MSAC and Mr. Schwartz, in his former capacity as a Maryland Assistant Attorney General, served on the MSAC.

\section{References}

1. Institute of Medicine: Approaching Death: Improving Care at the End of Life. Washington, DC: National Academies Press 1997, P. 5.

2. Blumenauer E: My near death panel experience. New York Times. November 15, 2009:WK12.

3. Corn BW: Ending end-of-life phobia-a prescription for enlightened health care reform. New Eng J Med 2009;361:e63.

4. Berwick DM: Launching accountable care organizationsthe proposed rule for the Medicare shared savings program. New Eng J Med 2011;364:e32.

5. Aulino F, Foley K: The project on death in America. J Royal Soc Med 2001;94:492-495.

6. Means to a Better End: A Report on Dying in America Today. Last Acts. November 2002. www.rwjf.org/pr/product .jsp?id = 15788 [Last accessed May 4, 2011.]

7. Community-State Partnerships to Improve End-of-Life Care: Grant Results Report. The Robert Wood Johnson Foundation. October 2004. www.rwjf.org/reports/npreports/csp .htm [Last accessed January 4, 2010.]

8. Advance Care Planning: Preferences for Care at the End of Life: Agency for Healthcare Research and Quality. March 2003. www.ahrq.gov/research/endliferia/endria.pdf [Last accessed January 4, 2010.] 
9. Advance Directives and Advance Care Planning: Report to Congress. Office of the Assistant Secretary for Planning and Evaluation. August 2008. http://aspe.hhs.gov/daltcp/ reports/2008/ADCongRpt.pdf [Last accessed January 4, 2010.]

10. 2010-12 Strategic Plan. National Hospice and Palliative Care Organization. 2009. www.nxtbook.com/nxtbooks/nhpco/ strategicplan2010-2012/\#/19/OnePage [Last accessed January 4, 2010.]

11. National Priorities Partnership Website. www.national prioritiespartnership.org/PriorityDetails.aspx?id =608 [Last accessed May 7, 2011

12. 2010 State Legislative Report. Americans United for Life. www.scribd.com/doc/45748671/2010-State-Session-Report [Last accessed May 4, 2011.]

13. Compassion and Choices Website. www.compassion andchoices.org/act/legislative_work [Last accessed January 4, 2010.]

14. Massachusetts Commission on End of Life Care Website. www.endoflifecommission.org/ [Last accessed May 7, 2011.]

15. West Virginia Center for End-of-Life Care Website. www.wvendoflife.org/ [Last accessed May 7, 2011.]

16. State of Michigan Website. Michigan Commission on End of Life Care. Report to the Governor, August 2001. www .michigan.gov/documents/EOLreport_6987_7.pdf [Last accessed January 4, 2010.]

17. California Coalition for Compassionate Care Website. www.finalchoices.org/ [Last accessed January 4, 2010.]

18. Aaron HJ, Butler SM: A federalist approach to health reform: The worst way, except for all the others. Health Affairs 2008;27:725-735.

19. Byrnes JC: The Health Care Decisions Act of 1993. U Baltimore Law Rev 1994;23:1-70.

20. Hoffmann DH: The Maryland Health Care Decisions Act: Achieving the right balance? Maryland Law Rev 1994;53: 1064-1130.

21. Fillmore R: Hopkins and state team up on bioethics. Johns Hopkins Gazette. June 23, 1997. www.jhu.edu/gazette/ aprjun97/jun2397/bioeth.html [Last accessed January 4, 2010.]

22. Maryland Attorney General and Johns Hopkins Study Barriers to Effective End-of-Life Care: Grant Results Report, July 2000. The Robert Wood Johnson Foundation. www .rwjf.org/reports/grr/031630s.htm [Last accessed January 4, 2010.]
23. Chapter 265. Laws of Maryland 2002.

24. Maryland Code Health-General Article $\S 13-1602$.

25. Maryland Code Health-General Article $\S 13-1603$.

26. Chapter 434. Laws of Maryland 2011.

27. Office of the Maryland Attorney General Website. www.oag.state.md.us/Healthpol/MSAC/Bobo_letter.pdf [Last accessed January 4, 2010.]

28. Rushton C, Hutton N, Reder E, Hall B: Challenges and Opportunities to Improve Pediatric Palliative Care in Maryland. Baltimore: Johns Hopkins Children's Center, 2004.

29. Chapter 81. Laws of Maryland 2007.

30. Study of Health Care Services for Children with LifeThreatening Conditions. January 2008. Office of the Maryland Attorney General Website. www.oag.state.md.us/ Healthpol/SAC/Ped_Palliative_Care_Report_\%2001_30_08 .pdf [Last accessed January 4, 2010.]

31. Patient Protection and Affordable Care Act $2010 \S 2302$.

32. Maryland Code Criminal Law Article $\S 3-102$.

33. Krakauer R: Invictus: Increasing patient choice in advanced illness and end-of-life care. CBS Interactive Business Network. http://findarticles.com/p/articles/mi_hb5871/is_ 201104/ai_n57242787/pg_4/ [Last accessed May 7, 2011.]

34. www.oag.state.md.us/Healthpol/SAC/index.htm\#ethics [Last accessed May 7, 2011.]

35. Maryland Code Health-General Article § 5-603.

36. Office of the Maryland Attorney General Website. www .oag.state.md.us/Healthpol/AdvanceDirectives.htm [Last accessed June 1, 2011.]

37. Office of the Maryland Attorney General Website. State Advisory Council on Quality Care at the End of Life. www.oa.state.md.us/Healthpol/SAC/reportsCor.htm [Last ccessed June 1, 2011.]

Address correspondence to: Cynda Hylton Rushton, Ph.D., R.N., FAAN Johns Hopkins University School of Nursing 525 N. Wolfe Street

Box 420

Baltimore, MD 21201

E-mail: CRUSHTON@son.jhmi.edu 